\title{
Anuran diversity (Amphibia, Anura) in a Seasonal Forest fragment in southern Brazil
}

\author{
Veluma Ialú Molinari De Bastiani ${ }^{1,2}$ \& Elaine Maria Lucas ${ }^{1}$ \\ ${ }^{1}$ Programa de Pós-graduação em Ciências Ambientais, \\ Universidade Comunitária da Região de Chapecó - Unochapecó, \\ Rua Senador Atílio Fontana, 591 E, Efapi, CEP 89809-000, Chapecó, SC, Brazil.www.unochapeco.edu.br \\ ${ }^{2}$ Corresponding author: Veluma Ialú Molinari De Bastiani, e-mail: veluma@unochapeco.edu.br
}

BASTIANI, V.I.M. \& LUCAS, E.M. Anuran diversity (Amphibia, Anura) in a Seasonal Forest fragment in southern Brazil. Biota Neotrop. 13(1): http://www.biotaneotropica.org.br/v13n1/en/abstract?inventory+ bn02413012013

\begin{abstract}
The Atlantic Forest is the home to a diverse and threatened fauna of amphibians. However, knowledge on these species is still scarce to many of its ecosystems, such as the Seasonal Forest. This study was aimed at determining the diversity of anurans in Parque Estadual Fritz Plaumann (PEFP), located in the municipality of Concórdia, Santa Catarina, southern Brazil. The PEFP comprises 741 ha, and is the only Conservation Unit of Seasonal Forest in Santa Catarina state. From August 2010 to July 2011 we surveyed frogs fortnightly during four to ten days, from sunset until approximately midnight. Active, audio and visual searches were carried out at breeding sites and favorable areas to meet the species. The sampling effort of the survey was evaluated with species accumulation curve considering the field expeditions as sample units. The species composition of PEFP was compared with 16 other different vegetal formations of the Atlantic Forest biome through similarity analysis. Twenty-three species were recorded. The accumulation curve approached an asymptote, indicating that most species of the area were observed. Most species were observed in lentic habitats of open areas. The anuran species composition of PEFP was similar to other areas of Mixed Ombrophile Forest and Seasonal Forest in southern region. Although PEFP comprised a relatively small area, the occurrence of habitat specialists, endangered amphibians that dependent on the forest, indicates the importance of this area for the conservation of the regional fauna. The continuation of long-term standardized studies is needed to monitor the population dynamics of recorded species and support alternative management practices, aiming at the conservation of anurans at the Seasonal Forest.

Keywords: biodiversity, conservation, frogs, Atlantic Forest, Santa Catarina.
\end{abstract}

BASTIANI, V.I.M. \& LUCAS, E.M. Diversidade de anuros (Amphibia, Anura) em um remanescente de Floresta Estacional no sul do Brasil. Biota Neotrop. 13(1): http://www.biotaneotropica.org.br/v13n1/pt/abstr act?inventory+bn02413012013

Resumo: A Mata Atlântica abriga uma expressiva e ameaçada fauna de anfíbios, mas o conhecimento sobre as espécies ainda é bastante escasso para diversos de seus ecossistemas, como a Floresta Estacional. Este estudo teve como objetivo conhecer a diversidade de anuros no Parque Estadual Fritz Plaumann (PEFP), localizado no município de Concórdia, Santa Catarina, sul do Brasil. O PEFP possui 741 ha, sendo a única Unidade de Conservação de Floresta Estacional no estado de Santa Catarina. Durante os meses de agosto de 2010 a julho de 2011 realizamos amostragens quinzenais de quatro a dez dias, a partir do entardecer até aproximadamente a meia noite. Empregamos o método de busca ativa, visual e auditiva, em sítios reprodutivos e locais favoráveis ao encontro das espécies. A suficiência de amostragem foi avaliada através da curva de acumulação de espécies considerando as campanhas de campo como unidades amostrais. Utilizamos uma análise de similaridade para comparar a anurofauna do PEFP com outras 16 áreas de Mata Atlântica. Foram registradas 23 espécies. A curva de acumulação mostrou tendência à estabilização, indicando que grande parte das espécies da área foi registrada. A maioria foi observada em ambientes lênticos em área aberta. A composição da anurofauna do PEFP foi similar a áreas de Floresta Ombrófila Mista e Floresta Estacional da região sul. Apesar de o PEFP possuir uma área relativamente pequena, a ocorrência de anfíbios especialistas de hábitat e ameaçados de extinção evidencia a sua importância para a conservação da fauna regional. O prosseguimento de estudos sistematizados em longo prazo é importante para monitorar a dinâmica populacional das espécies registradas e subsidiar alternativas de manejo, visando a conservação da anurofauna de Floresta Estacional.

Palavras-chave: biodiversidade, conservação, anfibios, Mata Atlântica, Santa Catarina. 


\section{Introduction}

The Atlantic Forest is considered the second largest tropical rainforest of the American Continent, extending along the Brazilian coast from Piauí to Rio Grande do Sul states (Pinto et al. 2006), and to southeastern Paraguay and northeastern Argentina (Tabarelli et al. 2005). This biome originally covered approximately $1.350 .000 \mathrm{~km}^{2}$ of the Brazilian territory (Fundação... \& Instituto... 2002), of which only $12 \%$ remain, distributed in small and isolated fragments (Ribeiro et al. 2009).

Because of its wide variations in latitude, altitude, and climatic regimes (Pinto et al. 2006, Ribeiro et al. 2009), the Atlantic Forest exhibits high species richness and endemism rates (Brasil 2000). However, this biological diversity is currently endangered by the expansion of agricultural activities, increased population density, and the presence of the largest Brazilian industrial centers (Brasil 2000, Pinto et al. 2006). The few remnants of Atlantic Forest are currently limited to steep regions, where agricultural and extractive activities were difficult or unfeasible, or to few areas of legal protection (Fundação... et al. 1998). The Atlantic Forest is currently considered one of the 34 biodiversity hotspots of the world (Myers et al. 2000, Mittermeier et al. 2004), and the richest Brazilian biome. From this ecosystem, more than 400 species of anurans have been described and approximately $85 \%$ are endemic (Cruz \& Feio 2007).

Despite its high biodiversity, knowledge on the taxonomic status, biogeography and conservation status of the frogs of the Atlantic Forest is still scarce (Silvano \& Segalla 2005). This is associated to the lack of intermediate and long-term studies, surveys of the fauna from different regions (Silvano \& Segalla 2005), and the fast pace of human actions degrading natural habitats (Forlani et al. 2010).

Santa Catarina state was originally covered only by Atlantic Forest, distributed among the vegetation types of Dense Ombrophile Forest (DOF), Mixed Ombrophile Forest (MOF), Seasonal Forest (SF) and Grasslands (Klein 1978). The western region of the state is covered mainly by Mixed Ombrophile Forest (also called as Araucaria Forests), which in the past comprised $42 \%$ of the state, while Seasonal Forest occupied approximately $9 \%$ of the territory, and Grasslands represented $14 \%$ and generally forming spots within Araucaria Forests (Medeiros 2006). Among the vegetation types of the Atlantic Forest present in Santa Catarina, the Seasonal Forest is one of the most endangered formations and least protected as conservation units (Fundação... \& Instituto... 2002). Although the biome as a whole has been impacted by colonization (Câmara 2003), Seasonal Forests have more deforested areas, as its relief promoted agricultural activities, cattle ranching, and silviculture (Araujo et al. 2009).

The anurans of Santa Catarina state represent $15 \%$ of the described species in Brazil (Lucas 2008). Despite recent taxonomic studies (Kwet 2006, Garcia et al. 2007, Toledo et al. 2007, Garcia et al. 2008), few have focused on diversity and conservation of amphibians of the area (Hartmann et al. 2008, Lucas \& Fortes 2008, Lingnau 2009, Dallacorte 2010, Wachlevski \& Rocha 2010, Lucas \& Marocco 2011), and species from many areas are still poorly known (Lucas 2008). Knowledge on diversity of species in conservation units is also limited to few studies (Lucas \& Fortes 2008, Dallacorte 2010, Wachlevski \& Rocha 2010, Lucas \& Marocco 2011).

Given the scarcity of information on diversity and distribution of anurans in the Atlantic Forest in southern Brazil, especially in areas of Seasonal Forest, this study was aimed at 1) determining richness and composition frog species in a conservation unit of Santa Catarina state; 2) comparing its species composition with those of other Brazilian localities, and 3) identifying potential threats to frog conservation in the area. In addition to broaden the knowledge on the species diversity of the state, the information presented in this study may support analyses on the real effectiveness of amphibian conservation in conservation units.

\section{Materials and Methods}

\section{Study site}

The study was conducted at the Parque Estadual Fritz Plaumann (PEFP), located in the municipality of Concórdia, western Santa Catarina state, southern Brazil (27 $7^{\circ} 17^{\prime} 36^{\prime \prime} \mathrm{S}$ and $52^{\circ} 06^{\prime} 38^{\prime \prime} \mathrm{W}$; $400 \mathrm{~m}$ of altitude; 741 ha, Figure 1). PEFP is located by the reservoir of the Itá Hydroelectric Power Plant (Itá HPP), in the Uruguay river basin, and the Queimados river mouth. The climate in the region is mild mesothermal (Instituto... 2002). The average annual maximum temperature is $22{ }^{\circ} \mathrm{C}$ and the average annual minimum temperature is $13{ }^{\circ} \mathrm{C}$. The average annual rainfall is $2.000 \mathrm{~mm}$ (Leite \& Leão 2009) without a defined dry season (Instituto... 2002). Of the 741 ha, 265 ha correspond to an island formed during the creation of the reservoir of the Itá HPP. In this study, surveys were carried out only in continental portion, comprising 476 ha.

The PEFP is a conservation unit of integral protection, created in 2003, as a measure to compensate the environmental impacts created by the Itá HPP. The vegetation of the region is characterized by Seasonal Forest as part of the Atlantic Forest biome. This vegetation occurs in low altitudes (up to $800 \mathrm{~m}$ ) of the Uruguay river valley and its tributaries. The PEFP is the only conservation unit in Santa Catarina state that protects fragments of this forest type (Vitali \& Uhlig 2010). Although it is a protected area, some invasive exotic plant species are frequently found in the area, such as Hovenia dulcis (Japanese raisin tree) and Hedichyum coronarium (white garland lily) (Instituto... 2003).

\section{Data collection}

The data collection was carried out from August 2010 to July 2011. The fortnightly surveys, during four to ten days, a total sampling effort of approximately 350 hours/person. Sampling procedures began at sunset, with the aid of flashlights and ended approximately at midnight. The sampling method consisted of visual and audio searches in aquatic habitats used for the reproduction of species (sensu Scott Junior \& Woodward 1994) and in trails inside the forest and occasional encounters.

Eight aquatic reproductive sites were regularly sampled, consisted of four lentic habitats in open areas (marsh, Porto, Brum, and Mirante ponds), three lotic habitats inside the forest (Lajeado Cruzeiro, Linha, and Canafístula creeks) and a lotic habitat in forest edge (Temporary creek; Table 1). For ponds and marsh, the entire perimeter was surveyed, and in creeks, a section of approximately $300 \mathrm{~m}$ was sampled. Some physical features were recorded for each habitat, such as the hidroperiod (temporary or permanent), water flow (lentic or lotic), surface area $\left(\mathrm{m}^{2}\right)$, water column depth (m), type of predominant vegetation in the margins of each habitat and type of bottom (substrate with more than $50 \%$ of predominance). One or two breeding sites were sampled on each night. At the Linha and Canafístula creeks, the same $300 \mathrm{~m}$ of the creek was sampled, while in Lajeado Cruzeiro creek, different sections were sampled during the survey due to access conditions. During the day, the creeks, lentic habitats, and trails inside the forest were walked for the observation of diurnal species.

To identify potential threats to the conservation of amphibians at PEFP, we examined if direct or indirect human effects associated to land use were present. The most evident ones in the area, which have also been reported in other studies were characterized by the presence of exotic animals (e.g. Both et al. 2011) and plants (e.g. Martin \& 


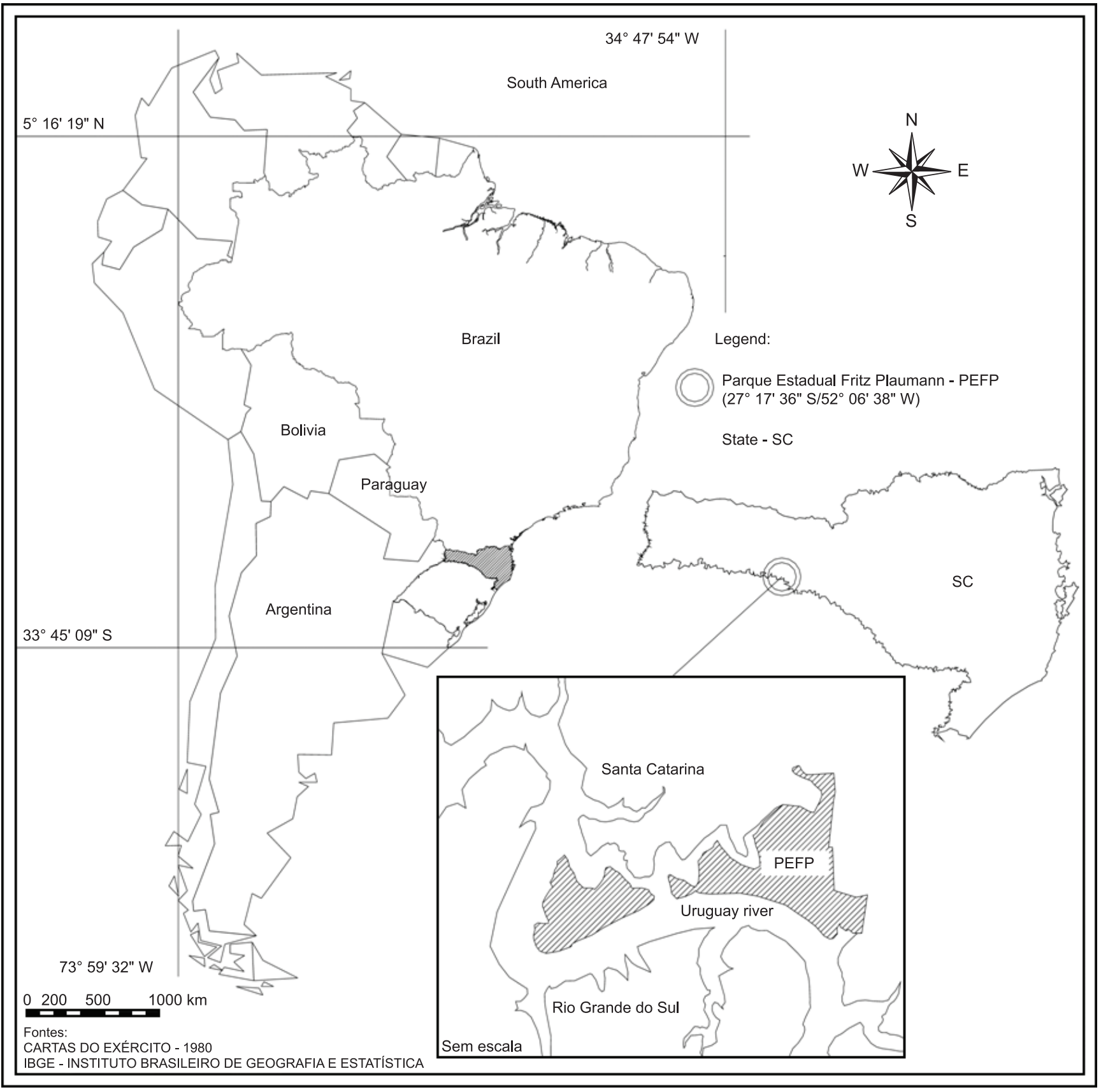

Figure 1. Location of the Parque Estadual Fritz Plaumann (PEFP) in Santa Catarina state, southern Brazil.

Murray 2011), presence of agricultural activities (e.g. Relyea 2005a, Kopp et al. 2007), presence or proximity of roads and/or human settlements (e.g. Hamer \& McDonnell 2008).

The species identification was carried out based on the literature, consultation with specialists and comparison with specimens deposited in scientific collections. To aid the taxonomic identification, calls of the species were recorded with a digital recorder. Voucher specimens were deposited in the scientific collection of the Universidade Comunitária da Região de Chapecó (Research Permit \# 04/2010/PAEFP/GERUC/DPEC and \# 13/2011/GERUC/DPECFATMA). The nomenclature and the taxonomic classification followed Frost (2011) and Pyron \& Wiens (2011).

\section{Data analysis}

To evaluate the sampling effort of the survey conducted in the eight bodies of water at the PEFP, species richness was estimated by extrapolating the species accumulation curve (Santos 2003), calculated on 21 sampling periods in the field. One thousand random repeats were performed with the software Estimates 7.5.0 (Colwell 2005). The species composition of PEFP was compared with those of other vegetal formations of the Atlantic Forest biome (Seasonal Forest, Mixed Ombrophile Forest and Coastal Ecosystem) (Table 2). Only Seasonal Forest was considered for the vegetation type of Seasonal Deciduous Forest and Seasonal Semideciduous Forest, due to the ongoing discussion about the distinction between them 
Table 1. Main characteristics of the eight bodies of water examined at the Parque Estadual Fritz Plaumann, Santa Catarina, southern Brazil, from August 2012 to July 2011. MAR = Marsh; PP = Porto Pond; $\mathrm{BP}=$ Brum Pond; $\mathrm{LCC}=$ Lajeado Cruzeiro Creek; $\mathrm{CC}=$ Canafístula Creek; $\mathrm{LC}=\mathrm{Linha} C \mathrm{Creek}$;C $=$ Temporary Creek; MP = Mirante Pond. TR = Trees (Aquifoliaceae, Boraginaceae, Euphorbiaceae, Fabaceae, Lauraceae, Malvaceae, Meliaceae, Myrtaceae, Arecaceae, Rhamnaceae, Rutaceae); SH = Shrubs (Annonaceae, Malpighiaceae, Solanaceae, Verbenaceae, Zingiberaceae); ESV = Erect Shrubby Vegetation (Asteraceae, Cyperaceae, Malvaceae, Poaceae, Pteridophyta); TSV = Tall Shrubby Vegetation ( $>30 \mathrm{~cm}$; Poaceae); SSV = Short Shrubby Vegetation $(<30 \mathrm{~cm}$; Poaceae); $\mathrm{M}=$ Macrophyte (Eichhornia crassipes, Salvinia sp., Eleocharis sp.); BG = Bare ground. The sequence of the types of vegetation in the items "Riverbed vegetation" and "Riverbank vegetation" indicates the decreasing predominance. $\mathrm{CH}=$ Cover by hydrophytes; $\mathrm{M}=\mathrm{Muddy}$; $\mathrm{PR}=\mathrm{Predominantly}$ rocky; $\mathrm{PM}=$ Predominantly muddy. $\mathrm{OA}=$ open area; $\mathrm{EN}=$ edge of native forest; $\mathrm{IN}=$ interior of native forest.

\begin{tabular}{|c|c|c|c|c|c|c|c|c|c|c|}
\hline Local & $\begin{array}{l}\text { Geographic } \\
\text { coordinates }\end{array}$ & $\begin{array}{l}\text { Altitude } \\
\text { (m) }\end{array}$ & Duration & $\begin{array}{l}\text { Area } \\
\left(m^{2}\right)\end{array}$ & $\begin{array}{c}\text { Depth } \\
\text { (m) }\end{array}$ & $\begin{array}{c}\text { Riverbed } \\
\text { vegetation }\end{array}$ & Riverbank vegetation & Floor & Ecosystem & Habitat \\
\hline MAR & $\begin{array}{l}27^{\circ} 17^{\prime} 22.9^{\prime \prime} \mathrm{S} \\
052^{\circ} 07^{\prime} 05.8^{\prime \prime} \mathrm{W}\end{array}$ & 403 & Temporary & $\sim 1600$ & 0.40 & M, ESV, SH & ESV, TSV, SSV, SH, TR & $\mathrm{CH}$ & Lentic & $\mathrm{OA}$ \\
\hline PP & $\begin{array}{l}27^{\circ} 18^{\prime} 16.6 ” \mathrm{~S} \\
052^{\circ} 06^{\prime} 04.8^{\prime \prime} \mathrm{W}\end{array}$ & 388 & Temporary & $\sim 350$ & 0.90 & M, ESV & TSV, SSV, SH, TR & $\mathrm{CH}$ & Lentic & $\mathrm{OA}$ \\
\hline $\mathrm{TC}$ & $\begin{array}{l}27^{\circ} 18^{\prime} 14.7^{\prime \prime} \mathrm{S} \\
052^{\circ} 06^{\prime} 05.4^{\prime \prime} \mathrm{W}\end{array}$ & 397 & Temporary & $\sim 800$ & 0.30 & Absent & BG, SSV, ESV, SH, TR & PM & Lotic & EN \\
\hline $\mathrm{BP}$ & $\begin{array}{l}27^{\circ} 18^{\prime} 18.8^{\prime \prime} \mathrm{S} \\
052^{\circ} 06^{\prime} 00.9^{\prime \prime} \mathrm{W}\end{array}$ & 380 & Permanent & $\sim 400$ & $\sim 0.40$ & M & ESV, TSV, SSV, SH, TR & M & Lentic & $\mathrm{OA}$ \\
\hline LCC & $\begin{array}{l}27^{\circ} 17^{\prime} 19.0^{\prime \prime} \mathrm{S} \\
052^{\circ} 06^{\prime} 50.8^{\prime \prime} \mathrm{W}\end{array}$ & 393 & Permanent & $\sim 1000$ & 0.60 & Absent & TR, ESV & PR & Lotic & IN \\
\hline $\mathrm{CC}$ & $\begin{array}{l}27^{\circ} 17^{\prime} 36.0^{\prime \prime} \mathrm{S} \\
052^{\circ} 06^{\prime} 38.7^{\prime \prime} \mathrm{W}\end{array}$ & 415 & Permanent & $\sim 290$ & 0.50 & Absent & ESV, SH, TR & PR & Lotic & IN \\
\hline LC & $\begin{array}{l}27^{\circ} 16^{\prime} 47.7^{\prime \prime} \mathrm{S} \\
052^{\circ} 06^{\prime} 24.7^{\prime \prime} \mathrm{W}\end{array}$ & 402 & Permanent & $\sim 300$ & 0.70 & Absent & ESV, SH, TR & PR & Lotic & IN \\
\hline MP & $\begin{array}{l}27^{\circ} 17^{\prime} 49.9 " \mathrm{~S} \\
052^{\circ} 06^{\prime} 53.6 " \mathrm{~W}\end{array}$ & 521 & Permanent & $\sim 120$ & 0.40 & M, ESV & ESV, TSV, SH, TR & M & Lentic & $\mathrm{OA}$ \\
\hline
\end{tabular}

Table 2. Richness of anuran species, sampling effort (months of study), study area, and plant formation of the localities compared with the Parque Estadual Fritz Plaumann. $\mathrm{CE}=$ coastal ecosystem (restinga); MOF = Mixed Ombrophile Forest; $\mathrm{SF}=$ Seasonal Forest.

\begin{tabular}{ccccll}
\hline $\begin{array}{c}\text { Formation/ } \\
\text { Ecosystem }\end{array}$ & $\begin{array}{c}\text { Size of the } \\
\text { area (ha) }\end{array}$ & $\begin{array}{c}\text { Sampling effort } \\
\text { (N. months) }\end{array}$ & $\begin{array}{c}\text { Number of } \\
\text { species }\end{array}$ & \multicolumn{1}{c}{ Local } & Reference \\
\hline CE & - & 12 & 15 & SC, Palhoça & Wachlevski \& Rocha (2010) \\
CE & Aprox. 30000 & 11 & 20 & SP, Peruíbe & Narvaes et al. (2009) \\
CE & - & 19 & 29 & RS, Torres & Colombo et al. (2008) \\
MOF & - & 13 & 21 & SC, Ipuaçu & Hartmann et al. (2008) \\
MOF & 876.7 & 15 & 32 & PR, Fazenda Rio Grande & Conte \& Rossa-Feres (2007) \\
MOF & 1606 & 37 & 26 & SC, Chapecó and Guatambú & Lucas \& Fortes (2008) \\
MOF & 12839 & 2 & 29 & SC, Ponte Serrada and Passos Maia & Lucas \& Marocco (2011) \\
MOF & - & 13 & 23 & PR, Tijucas do Sul & Conte \& Machado (2005) \\
MOF & Aprox. 4500 & 48 & 55 & RS, São Francisco de Paula & Kwet et al. (2010) \\
MOF & 747 & 26 & 32 & SC, Lebon Régis & Lingnau (2009) \\
SF & 2178.84 & 35 & 34 & SP, Gália and Alvinlândia & Brassaloti et al. (2010) \\
SF & 2069.06 & 4 & 24 & SP, Pedregulho & Araujo et al. (2009) \\
SF & 243 & 12 & 24 & SP, Rio Claro & Zina et al. (2007) \\
SF & 2222.80 & 17 & 21 & SP, Rio Claro - FEENA & Toledo et al. (2003) \\
SF & 17491 & 12 & 31 & RS, Derrubadas & Iop et al. (2011) \\
SF & - & - & 23 & RS, Quarta Colônia & Cechin et al. (2002) \\
SF & 476 & 12 & 23 & SC, Concórdia & Present study \\
\hline
\end{tabular}

(Oliveira-Filho et al. 2006, Pennington et al. 2009). The similarity analysis was carried out using the Jaccard coefficient of affinity, with later clustering analysis with the weighted pair group method using arithmetic averaging (WPGMA) (Krebs 1999). To avoid the interference of taxonomic issues, we excluded from the analysis species classified as undetermined, such as: "sp." (unidentified species), "gr." (species group), "aff." (affinis) and "cf." (confer). The exotic species Lithobates catesbeianus was also excluded from the analysis. The consistency of the similarity analysis was determined based on cophenetic correlation coefficient (r) (Romesburg 1984), to verify the loss of information for the construction of dendrogram. This coefficient was obtained by correlating the original similarity matrix obtained from the dendrogram, with $r$ values $\geq 0.9$ considered very good fit, $0.8 \leq \mathrm{r}<0.9$ good fit; $0.7 \leq \mathrm{r}<0.8$ poor fit, and $\mathrm{r}<0.7$ very poor fit (Rohlf 2000).

To examine if the geographic distance influenced the composition of anuran species and consequently the result of similarity analysis, we performed the Mantel test (Manly 2000), using the Jaccard coefficient 
for the similarity matrix and the euclidean distance coefficient for the geographic distance matrix with 5.000 permutations. The geographic distance was calculated based on geographic coordinates of the areas. All analyses were performed with the software Past (Hammer et al. 2001). The significance level for all tests was set at $\mathrm{p}<0.05$ (Zar 1999).

\section{Results}

We recorded 23 species of anuran amphibians, 22 native and one exotic, distributed in 15 genera and eleven families (Table 3). Hylidae was the most representative family, with eight species, followed by Leptodactylidae and Bufonidae (3), Leiuperidae (2) and Alsodidae, Brachycephalidae, Centrolenidae, Hylodidae, Microhylidae Odontophrynidae and Ranidae (1). The latter was represented by the exotic species Lithobates catesbeianus. The species accumulation curve approached an asymptote, indicating that most species of the area were observed during the study (Figure 2).
Richness of native species was highest in lentic habitats than in open areas $(72.7 \% ; \mathrm{n}=16)$, and lowest in lotic habitats inside or at the edge of the native forest $(50 \% ; n=11$; Table 3$)$. The cluster analysis (Figure 3 ) revealed that the anuran assemblage of the Parque Estadual Fritz Plaumann was more similar to that of the Parque Estadual do Turvo (Iop et al. 2011), located in Rio Grande do Sul state, and covered by Seasonal Forest. The anuran composition of these two areas was similar to those of other two areas in Santa Catarina state, Ipuaçu (Hartmann et al. 2008), characterized by Mixed Ombrophile Forest and the Floresta Nacional de Chapecó (Lucas \& Fortes 2008), characterized by the transition between MOF and SF, also geographically close. These four areas combined with two other sites mainly in MOF and SF localities in Southern Brazil comprise a group with about $50 \%$ similarity, while a second group with approximately $45 \%$ similarity consists of localities in SF of southeastern Brazil. The cophenetic correlation coefficient indicated that the similarity analysis was consistent $(r=0.92)$. Geographically

Table 3. Species of anurans and habitats examined at the Parque Estadual Fritz Plaumann, Santa Catarina, southern Brazil, between August 2010 and July 2011. IN = interior of native forest; $\mathrm{EN}=$ edge of native forest; $\mathrm{OA}=$ open area. *leaf litter, in trail inside forest.

\begin{tabular}{|c|c|c|c|}
\hline \multirow{2}{*}{ Family/specie } & \multicolumn{3}{|c|}{ Habitat } \\
\hline & IN & EN & $\mathbf{O A}$ \\
\hline \multicolumn{4}{|l|}{ Alsodidae } \\
\hline Limnomedusa macroglossa (Duméril \& Bibron, 1841) & $\mathrm{X}$ & & \\
\hline \multicolumn{4}{|l|}{ Brachycephalidae } \\
\hline Ischnocnema henselii (Peters, 1872)* & $\mathrm{X}$ & & \\
\hline \multicolumn{4}{|l|}{ Bufonidae } \\
\hline Melanophryniscus sp. & $\mathrm{X}$ & $\mathrm{X}$ & \\
\hline Rhinella henseli (Lutz, 1934) & $\mathrm{X}$ & & $\mathrm{X}$ \\
\hline Rhinella icterica (Spix, 1824) & $\mathrm{X}$ & & $\mathrm{X}$ \\
\hline \multicolumn{4}{|l|}{ Centrolenidae } \\
\hline Vitreorana uranoscopa (Müller, 1924) & $\mathrm{X}$ & & \\
\hline \multicolumn{4}{|l|}{ Hylidae } \\
\hline Dendropsophus minutus (Peters, 1872) & & & $\mathrm{X}$ \\
\hline Hypsiboas bischoff (Boulenger, 1887) & & & $\mathrm{X}$ \\
\hline Hypsiboas curupi Garcia, Faivovichi \& Haddad, 2007 & $\mathrm{X}$ & & \\
\hline Hypsiboas faber (Wied-Neuwied, 1821) & $\mathrm{X}$ & & $\mathrm{X}$ \\
\hline Phyllomedusa tetraploidea Pombal \& Haddad, 1992 & & & $\mathrm{X}$ \\
\hline Scinax aromothyella Faivovich, 2005 & $\mathrm{X}$ & & $\mathrm{X}$ \\
\hline Scinax fuscovarius (A. Lutz, 1925) & & & $\mathrm{X}$ \\
\hline Scinax perereca Pombal, Haddad \& Kasahara, 1995 & & & $\mathrm{X}$ \\
\hline \multicolumn{4}{|l|}{ Hylodidae } \\
\hline Crossodactylus schmidti Gallardo, 1961 & $\mathrm{X}$ & & \\
\hline \multicolumn{4}{|l|}{ Leiuperidae } \\
\hline Physalaemus cuvieri Fitzinger, 1826 & & & $\mathrm{X}$ \\
\hline Physalaemus aff. gracilis (Boulenger, 1883) & & & $\mathrm{X}$ \\
\hline \multicolumn{4}{|l|}{ Leptodactylidae } \\
\hline Leptodactylus latrans (Steffen, 1815) & & & $\mathrm{X}$ \\
\hline Leptodactylus mystacinus (Burmeister, 1861) & & & $\mathrm{X}$ \\
\hline Leptodactylus plaumanni Ahl, 1936 & & & $\mathrm{X}$ \\
\hline \multicolumn{4}{|l|}{ Microhylidae } \\
\hline Elachistocleis bicolor (Guérin-Menéville, 1838) & & & $\mathrm{X}$ \\
\hline \multicolumn{4}{|l|}{ Odontophrynidae } \\
\hline Proceratophrys bigibbosa (Peters, 1872) & $\mathrm{X}$ & $\mathrm{X}$ & \\
\hline \multicolumn{4}{|l|}{ Ranidae } \\
\hline Lithobates catesbeianus (Shaw, 1802) & $\mathrm{X}$ & & $\mathrm{X}$ \\
\hline Species richness & 12 & 2 & 17 \\
\hline
\end{tabular}




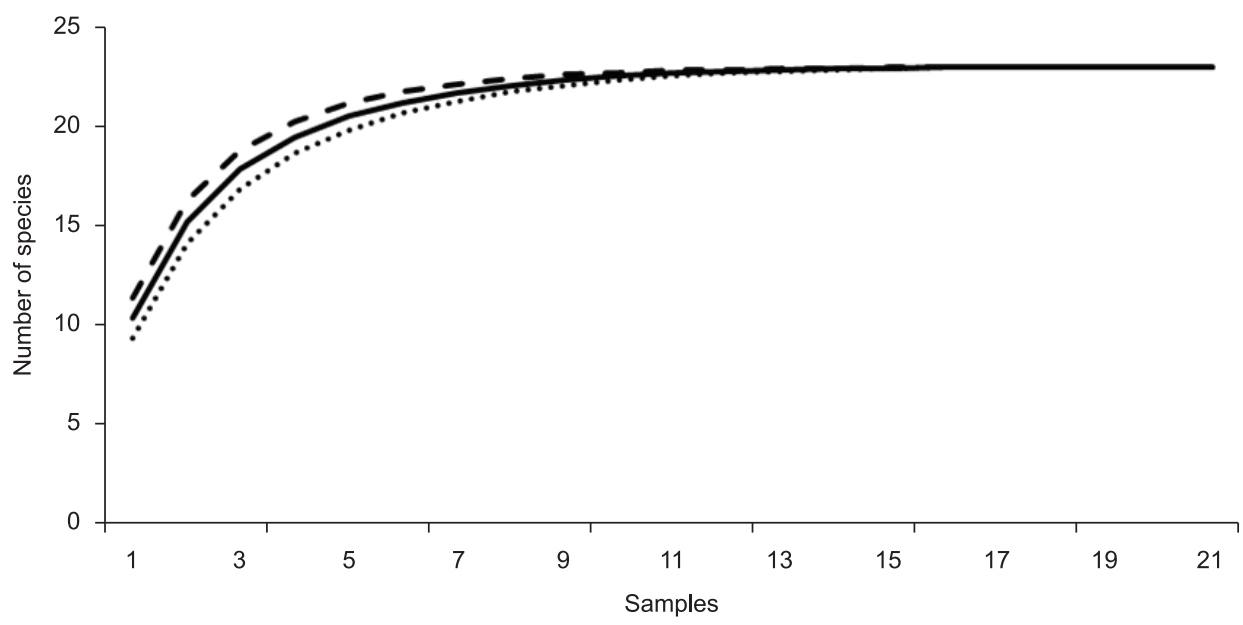

Mean _ - Standard deviation positive

Figure 2. Species accumulation curves, calculated based on 21 sampling periods in the field, from August 2010 to July 2011 at the Parque Estadual Fritz Plaumann, Santa Catarina, southern Brazil, from 1.000 randomizations.

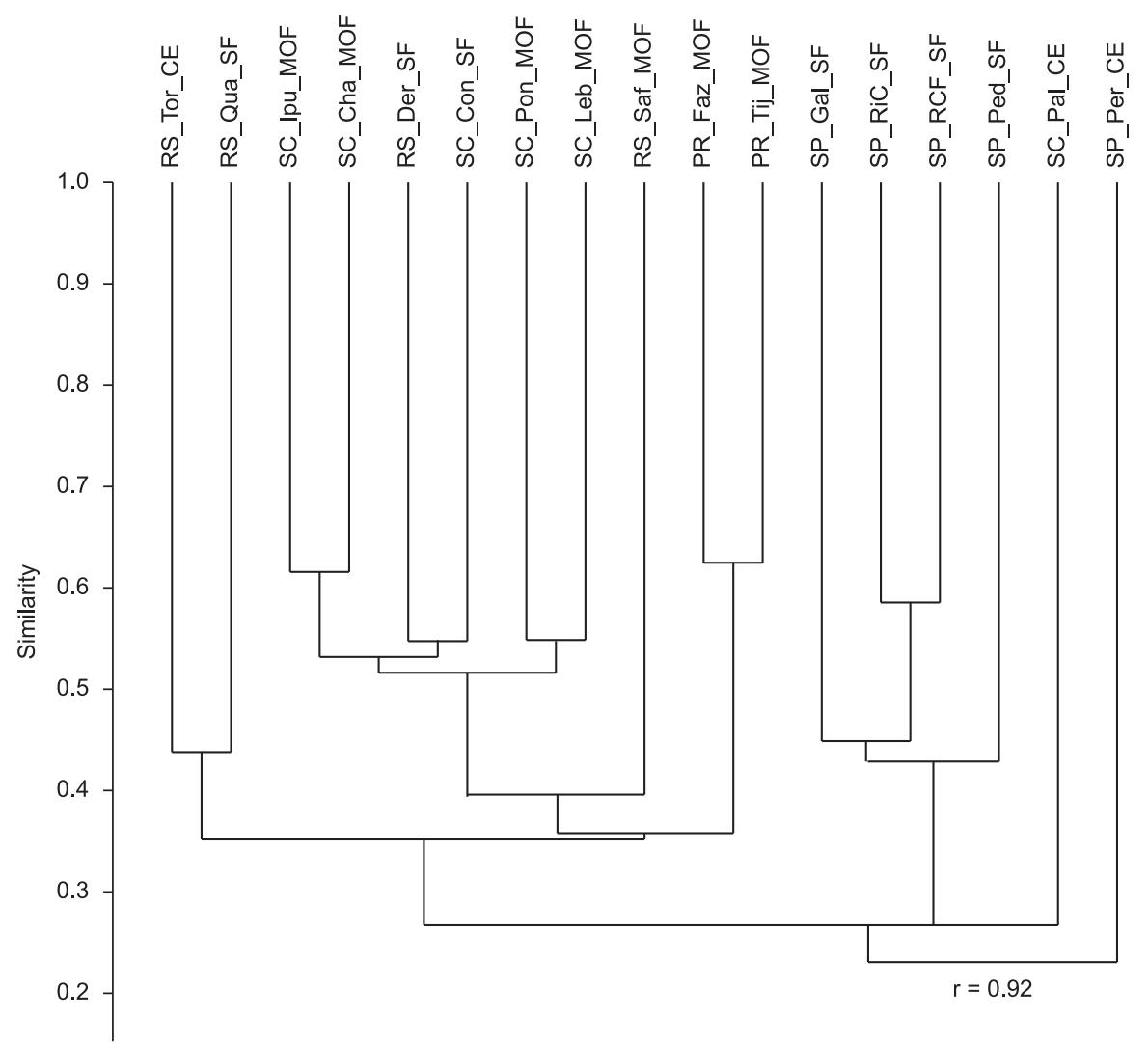

Figure 3. Similarity in species composition of anurans among Brazilian localities, based on the Jaccard coefficient of affinity, and later cluster analysis with WPGMA. The legend indicates the geographic location of the areas, considering state, county and type of vegetation, respectively. State: SP = São Paulo; $\mathrm{PR}=$ Paraná; $\mathrm{SC}=$ Santa Catarina; $\mathrm{RS}=$ Rio Grande do Sul; County: Gal = Gália and Alvilândia; RiC = Rio Claro; $\mathrm{RCF}=$ Rio Claro (FEENA); Ped $=$ Pedregulho; Per = Peruíbe; Faz = Fazenda Rio Grande; Tij = Tijucas do Sul; Ipu = Ipuaçu; Cha = Chapecó and Guatambú; Con = Concórdia; Pon = Ponte Serrada and Passos Maia; Leb = Lebón Regis; Pal = Palhoça; Tor = Torres; Qua = Quarta Colônia; Der = Derrubadas; SaF = São Francisco de Paula. Formação/ecossistema: $\mathrm{SF}=$ Floresta Estacional; $\mathrm{MOF}=$ Floresta Ombrófila Mista; $\mathrm{CE}=$ Ecossistema Costeiro (restinga). $\mathrm{r}=$ cophenetic correlation coeficiente.

closer assemblages of anurans were more similar regarding species composition $(\mathrm{r}=0.56, \mathrm{p}=0.00)$.

Five threatened or "near threatened" species were observed in the area. Crossodactylus schmidti and Proceratophrys bigibbosa are in the category "near threatened" according to the IUCN Red List of
Threatened Species (International... 2011). Crossodactylus schmidti is in the category "critically endangered", Limnomedusa macroglossa and Hypsiboas curupi are "endangered" and Vitreorana uranoscopa is "vulnerable" according to the List of Species of Threatened Fauna of Santa Catarina State (Conselho... 2011). 
The potential threats to the anurans observed were the presence of exotic species of animals and plants, especially inside the conservation unit, and agricultural activities in the surrounding areas, with possible use of pesticides. The exotic species Lithobates catesbeianus (American bullfrog) was present in five of the eight sampled habitats. Hovenia dulcis (Japanese raisin tree) and Hedichyum coronarium (white garland lily) were present in most waterbodies examined especially lotic habitats. Hedichyum coronarium, possibly due to its predominance in the margins of some aquatic habitats, was frequently used as calling sites and shelter by Hypsiboas curupi and Scinax aromothyella. Agricultural activities, as well as silviculture of Pinus and Eucalyptus and human settlements in the surrounding area were commonly observed. Solid waste from domestic and agricultural (e.g. plastic bags, sacks, other packaging like PET bottles and pots, tire rubber, clothing, aluminum cans) were very common, especially in Lajeado Cruzeiro creek, which crosses the conservation unit.

\section{Discussion}

The anurans recorded at PEFP represent $16 \%$ of the amphibians occurring in Santa Catarina state (144 species) (Lucas 2008), 5.6\% of the known frogs of Atlantic Forest (405 species) (Haddad \& Prado 2005 ) and $2.4 \%$ of the fauna of amphibians currently known in Brazil (913 species) (Sociedade... 2012). The species accumulation curve indicates that the study recorded most of the richness of the area, despite the occurrence of at least 15 additional species in other areas of Seasonal Forest and Mixed Ombrophile Forest in southern Brazil (e.g. Lucas 2008, Iop et al. 2011, Marocco et al. 2011). However, the anuran richness found is similar to the reported in other fragments of Mixed Ombrophile Forest in western Santa Catarina state (Hartmann et al. 2008, Lucas \& Fortes 2008, Lingnau 2009, Lucas \& Marocco 2011).

The anuran community in the study area is characteristic of interior formations of Atlantic Forest with $40.9 \%$ of species with distribution restricted to southern Brazil (Ischnocnema henselii, Rhinella henseli, Limnomedusa macroglossa, Proceratophrys bigibbosa, Hypsiboas curupi, Scinax aromothyella, Crossodactylus schmidti, Leptodactylus plaumanni and Elachistocleis bicolor) or to others southern countries of South America (Frost 2011). The similarity analysis regarding the composition of anuran species revealed the importance of geographic distance and plant cover in the structure of anuran assemblages of the study area and of other localities of Atlantic Forest in southeastern and southern Brazil included in the comparison. The importance of biogeographic factors in community structure has been demonstrated (Ricklefs \& Schluter 1993) and reported in other studies on amphibians of Atlantic Forest (e.g. Zina et al. 2007, Lucas \& Fortes 2008, Rocha et al. 2008).

The highest species richness were found in lentic ecosystems of open areas, with several species exclusively from these habitats, such as Dendropsophus minutus, Scinax fuscovarius, Physalaemus cuvieri, Leptodactylus mystacinus and Leptodactylus latrans (Haddad \& Prado 2005, Brassaloti et al. 2010). Several studies on anuran assemblages in South America (e.g. Conte \& Machado 2005, Vasconcelos \& Rossa-Feres 2005, Araujo et al. 2009, Lucas \& Marocco 2011) have shown this pattern, in which most species is typical of open areas and reproduce in lentic habitats (Haddad \& Prado 2005), and comparatively few species are restricted to forest habitats and have a reproductive mode exclusively associated with lotic habitats. This pattern in habitat use is possibly associated with phylogenetic constraints of the species (Zimmerman \& Simberlof 1996), resulted from a combination of factors, such as predation, competition, and habitat variables. In addition, the predominance of generalist species associated with open areas in assemblages from regions originally covered by Atlantic Forest might be due to the intense destruction and reduction of the biome (Ribeiro et al. 2009). Many species typical of wet habitats in the forest might have been eliminated due to deforestation, resulting in an impoverishment of the specialized fauna in detriment of the permanence of generalist species or those resistant to environmental disturbances (Haddad \& Prado 2005, Conte \& Rossa-Feres 2007).

In PEFP, the species associated with well-preserved habitats (Vitreorana uranoscopa, Proceratophrys bigibbosa, Crossodactylus schmidti, and Hypsiboas curupi) and whose reproductive modes are exclusively dependent of lotic habitats in or at the edge of the forest (Kwet \& Faivovich 2001, Brassaloti et al. 2010, Gallardo 1961, Garcia et al. 2007) are the most vulnerable to local extinction. This type of habitat has become gradually more scarce in the study region, mainly due to the deforestation of gallery forests along creeks for the expansion of agricultural and cattle ranching activities, and the conversion of lotic into lentic habitats with the construction of dams and pollution of waters with chemicals from agricultural activities (Bonai et al. 2009, Ternus et al. 2011). On a large-scale, changes in lotic habitats inside forest may have an negative impact on the amphibian populations that use these habitats along their distributions (Becker et al. 2010, Toledo et al. 2010).

Some species associated to forest habitats in PEFP are considered endangered in lists of species threatened with extinction. The occurrence these species indicates the need of conservation plans based on intermediate and long-term studies, supporting the suggestions of the National Action Plan for the Conservation of Endangered Reptiles and Amphibians of Southern Brazil (Directive 25 , of $17^{\text {th }}$ February 2012) (Brasil 2012). Lucas \& Garcia (2011) recently reported C. schmidti in westernmost Santa Catarina, and the population observed during the present study is the second record for the state and the first for the species in a conservation unit in the state (Bastiani et al. 2012). In addition, one of the two populations of $H$. curupi known to occur in conservation units was found in the study area (Lucas \& Garcia 2011, Lucas \& Marocco 2011).

The conservation implications associated with the occurrence of exotic animal and plant species, and human settlements around the park need to be examined in detail, as environmental changes may cause extinctions and population declines (Bishop et al. 2012). Lithobates catesbeianus is known for its potential as an invasive species (Both et al. 2011), competing with native species (Alves et al. 2008) and harboring pathogens (see Cunha \& Delariva 2009). The exotic plants Hedychium coronarium (white garland lily) and Hovenia dulcis (Japanese raisin tree) interfere in the structure of the vegetation at the margin of water bodies, and can affect species that use the vegetation as a reproductive site or shelter. Although Hedychium coronarium is used by some anurans (see also Colombo et al. 2008), it dominates the margins of aquatic habitats, making them homogeneous, while Hovenia dulcis can have an allelopathic effect (Wandscheer et al. 2011), in addition to still unknown implications caused by the large size of its leaves and fruits in creeks and ponds. The evaluation of the impact of exotic fauna and flora on native species focused on management strategies is especially important as this is a conservation unit, whose main goal is to protect biodiversity.

In addition to threats inside the PEFP, in the surrounding area, agricultural activities, silviculture of Pinus and Eucalyptus, and human settlements are commonly observed. They cause changes in water quality, and loss and degradation of natural habitats (Peltzer et al. 2003, Machado et al. 2012) due to the presence of human residues (Hamer \& McDonnell 2008) in aquatic habitats in the park, and the contamination by chemical products used in crops. The occurrence of exotic plant species, such as Pinus and Eucalyptus, has a negative influence on anuran assemblages, reducing anuran richness and abundance, and changing anuran composition (Machado et al. 2012). The contamination by pesticides from agricultural activities may result in death or abnormalities, mainly in anuran larva (e.g. Gurushankara et al. 2007, Krishnamurthy et al. 2008) and induce cellular and genetic alterations (Lajmanovich et al. 1998), malformations and sex-reversing in adults (Hayes et al. 2002, 2010). The exposure and effects of amphibians to pesticides also 
needs to be further investigated, as it can reveal contamination in many compartments of the ecosystem (Lajmanovich et al. 2005, Schneider et al. 2009), as well as changes in ecological interactions that can possibly cause environmental imbalance (Lajmanovich et al. 2003, Mann et al. 2003, Relyea 2005b).

Although the area of PEFP is relatively small with vegetation in different successional stages, the occurrence of endangered habitat specialists that depend on forests show the importance of the area for the conservation of the regional fauna, as forest fragments are scarce in the plateau region of Santa Catarina (Ribeiro et al. 2009). This forest fragment plays an important role in the connection with other conservation units (Floresta Nacional de Chapecó, Parque Nacional das Araucárias, and Parque Estadual do Turvo), through the implementation of proposals of ecological corridors, such as the Timbó Corridor (State Decree 2.956, of $20^{\text {th }}$ of January 2010) (Santa Catarina 2010a) and the Chapecó Corridor (State Decree 2.957, of $20^{\text {th }}$ of January 2010) (Santa Catarina 2010b). The continuation of long-term standardized studies is needed in this conservation unit in order to monitor the population dynamics of species, especially threatened ones, and seek alternatives to manage exotic species, better understand potential threats to preserve the fauna of PEFP and the Seasonal Forest, one of the most threatened vegetation types of the Atlantic Forest.

\section{Acknowledgements}

We thank Fundação do Meio Ambiente do Estado de Santa Catarina - FATMA, Fundação de Amparo à Pesquisa e Inovação do Estado de Santa Catarina - FAPESC and the Co-Management Team of the Parque Estadual Fritz Plaumann - ECOPEF for logistical and financial support. We also thank all those who participated in field work, especially to Murilo A. Nichele and Adelar A. Osowski, to Tiago Gomes dos Santos and Samanta Iop for helping in statistical analysis and Raúl Maneyro and two anonymous reviewers for the comments and suggestions on the manuscript and Cristina O. GridiPapp for the English version.

\section{References}

ALVES, F.C., BRANCO, A., LUCAS, E.M. \& FORTES, V.B. 2008. Ocorrência da espécie exótica Lithobates catesbeianus (rã-touro) em ambientes naturais nos municípios de Chapecó e Guatambu, Santa Catarina, Brasil. Acta Ambient. Catarin. 5(1-2):35-42.

ARAUJO, C.O., CONDEZ, T.H. \& SAWAYA, R.J.S. 2009. Anfíbios Anuros do Parque Estadual das Furnas do Bom Jesus, sudeste do Brasil, e suas relações com outras taxocenoses no Brasil. Biota Neotrop. 9(2): http:// www.biotaneotropica.org.br/v9n2/pt/abstract?article+bn01309022009.

BASTIANI, V.I.M., GARCIA, P.C.A \& LUCAS, E.M. 2012. Crossodactylus schmidti Gallardo, 1961 (Anura: Hylodidae) in Santa Catarina State, southern Brazil: a new record and comments on its conservation status. Check List. 8(2):262-263.

BECKER, C. G., FONSECA, C. R., HADDAD, C. F. B. \& PRADO, P. I. 2010. Habitat split as a cause of local population declines of amphibians with aquatic larvae. Cons. Biol. 24:287-294. http://dx.doi.org/10.1111/j.15231739.2009.01324.x

BISHOP, P.J., ANGULO, A., LEWIS, J.P., MOORE, R.D., RABB, G.B. \& MORENO, J.G. 2012. The amphibian extinction crisis: what will it take to put the action into the Amphibian Conservation Action Plan? Sapiens (Online) 5.2. http://sapiens.revues.org/1406.

BONAI, N., SOUZA-FRANCO, G.M., FOGOLARI, O., MOCELLIN, D.J.C \& DAL MAGRO, J. 2009. Heavy metal distribution of sediments in the Itá Reservoir, Brazil. Acta Limnol. Bras. 21:10-20.

BOTH, C., LINGNAU, R., SANTOS JUNIOR, A., MADALOZZO, B., LIMA, L.P. \& GRANT, T. 2011. Widespread occurence of the American Bullfrog, Lithobates catesbeianus (Shaw, 1802) (Anura: Ranidae) in Brazil. South Am. J. Herpetol. 6(2):127-134. http://dx.doi.org/10.2994/057.006.0203
BRASIL. Ministério do Meio Ambiente - MMA. 2000. Avaliação e ações prioritárias para a conservação da biodiversidade da Mata Atlântica e Campos Sulinos. Conservation International do Brasil, Fundação SOS Mata Atlântica, Fundação Biodiversitas, Instituto de Pesquisas Ecológicas, Secretaria do Meio Ambiente do Estado de São Paulo, SEMAD/Instituto Estadual de Florestas-MG. MMA/SBF, Brasília, 40p.

BRASIL. Ministério do Meio Ambiente - MMA. 2012. Portaria ${ }^{\circ}$ 25, de 17 de fevereiro de 2012. Aprova o Plano de Ação Nacional para Conservação de Répteis e Anfíbios Ameaçados da Região Sul do Brasil - PAN Herpetofauna do Sul contemplando 50 espécies, dentre elas, cinco ameaçadas de extinção (In MMA n ${ }^{\circ}$ 03/2003), estabelecendo seu objetivo geral, objetivos específicos, ações, prazo de execução, abrangência e formas de implementação e supervisão. Diário Oficial da República Federativa do Brasil, Brasília, fev. 2012.

BRASSALOTI, R.A., ROSSA-FERES, D.C. \& BERTOLUCI, J. 2010. Anurofauna da Floresta Estacional Semidecidual da Estação Ecológica dos Caetetus, Sudeste do Brasil. Biota Neotrop. 10(1): http://www. biotaneotropica.org.br/v10n1/pt/abstract?article+bn01810012010.

CÂMARA, I.G. 2003. Brief history of conservation in the Atlantic Forest. In The Atlantic Forest of South America: biodiversity status, threats, and outlook (C. Galindo-Leal \& I.G. Câmara, eds.). Center for Applied Biodiversity Science and Island Press, Washington, p.31-42.

CECHIN, S.Z., GIASSON, L.O., HARTMANN, M.A., SANTOS, T.G. \& BOELTER, R. 2002. Anfíbios. In Quarta Colônia. Inventários Técnicos: Flora e Fauna (J. Itaqui, org.). Santa Maria, p.201-205.

COLOMBO, P., KINDEL, A., VINCIPROVA, G. \& KRAUSE, L. 2008. Composição e ameaças à conservação dos anfíbios anuros do Parque Estadual de Itapeva, município de Torres, Rio Grande do Sul, Brasil. Biota Neotrop. 8(3): http://www.biotaneotropica.org.br/v8n3/pt/ abstract?article+bn01208032008.

COLWELL, R.K. 2005. Estimates: statistical estimation of species richness and shared species from samples. version 7.5. User's Guide. http://purl. oclc.org/estimates.

CONSELHO ESTADUAL DO MEIO AMBIENTE - CONSEMA, 2011. Lista de Espécies da Fauna Ameaçadas de Extinção no Estado de Santa Catarina. http://ignis.org.br/lista/ (último acesso em 20/2011).

CONTE, C.E. \& MACHADO, R.A. 2005. Riqueza de espécies e distribuição espacial e temporal em comunidade de anuros (Amphibia, Anura) em uma localidade de Tijucas do Sul, Paraná, Brasil. Rev. Bras. Zool. 22(4):940-948. http://dx.doi.org/10.1590/S010181752005000400021

CONTE, C.E. \& ROSSA-FERES, D.C. 2007. Riqueza e distribuição espaçotemporal de anuros em um remanescente de Floresta de Araucária no sudeste do Paraná. Rev. Bras. Zool. 24(4):1025-1037. http://dx.doi. org/10.1590/S0101-81752007000400020

CRUZ, C.A.G. \& FEIO, R.N. 2007. Endemismos em anfíbios em áreas de altitude na Mata Atlântica no sudeste do Brasil. In Herpetologia no Brasil II (L. B. Nascimento \& M. E. Oliveira, eds.). Sociedade Brasileira de Herpetologia, Belo Horizonte, p.117-126.

CUNHA, E.R. \& DELARIVA, R.L. 2009. Introdução da rã-touro, Lithobates catesbeianus (Shaw, 1802): uma revisão. Rev. Saúde e Biol. 4(2):34-46.

DALLACORTE, F. 2010 . Impacto da Rã-touro-gigante (Lithobates catesbeianus) sobre a fauna nativa na zona de amortecimento e interior do Parque Nacional da Serra do Itajaí (PNSI), Blumenau - SC. Dissertação de mestrado, Universidade Regional de Blumenau, Blumenau.

FORLANI, M.C., BERNARDO, P.H., HADDAD, C.F.B. \& ZAHER, H. 2010. Herpetofauna do Parque Estadual Carlos Botelho, São Paulo, Brasil. Biota Neotrop. 10(3): http://www.biotaneotropica.org.br/v10n3/ pt/abstract?article+bn00210032010.

FROST, D.R. 2011. Amphibian Species of the World: an Online Reference. version 5.5. American Museum of Natural History, New York. http://research.amnh.org/vz/herpetology/amphibia/ (último acesso em 31/01/2011).

FUNDAÇÃO SOS MATA ATLÂNTICA \& INSTITUTO NACIONAL DE PESQUISAS ESPACIAIS - INPE. 2002. Atlas dos remanescentes florestais da Mata Atlântica e ecossistemas associados no período de 1995-2000. São Paulo. Relatório final. 
FUNDAÇÃO SOS MATA ATLÂNTICA, INSTITUTO NACIONAL DE PESQUISAS ESPACIAIS - INPE \& INSTITUTO SOCIOAMBIENTAL. 1998. Atlas da evolução dos remanescentes florestais da Mata Atlântica e ecossistemas associados no período de 1990-1995. São Paulo.

GALLARDO, J.M. 1961. Anfibios anuros de Misiones con la descripción de una nueva espécie de Crossodactylus. Neotropica. 7:33-38.

GARCIA, P.C.A., FAIVOVICH, J. \& HADDAD, C.F.B. 2007. Redescription of Hypsiboas semiguttatus, with the description of a new species of the Hypsiboas pulchellus group. Copeia. 4:933-951. http://dx.doi. org/10.1643/0045-8511(2007)7[933:ROHSWT]2.0.CO;2

GARCIA, P.C.A., PEIXOTO, O.L. \& HADDAD, C.F.B. 2008. A new species of Hypsiboas (Anura: Hylidae) from the Atlantic Forest of Santa Catarina, Southern Brazil, with commentson its conservation status. South Am. J. Herpetol. 3(1):27-35. http://dx.doi.org/10.2994/18089798(2008)3[27:ANSOHA]2.0.CO;2

GURUSHANKARA, H.P., KRISHNAMURTHY, S.V. \& VASUDEV, V. 2007. Morphological normalities in natural populations of common frogs inhabiting agroecosystems of central Western Ghats. Applied Herpetology. 4:39-45. http://dx.doi.org/10.1163/157075407779766651

HADDAD, C.F.B. \& PRADO, C.P.A. 2005. Reproductive modes in frogs and their unexpected diversity in the Atlantic Forest of Brazil. BioScience. 55(3):207-217. http://dx.doi.org/10.1641/00063568(2005)055[0207:RMIFAT]2.0.CO;2

HAMER, A.J. \& McDONNELL, M.J. 2008. Amphibian ecology and conservation in the urbanising in the world: a review. Biol. Conserv. 141:2432-2449. http://dx.doi.org/10.1016/j.biocon.2008.07.020

HAMMER, O., HARPER, D.A.T. \& RYAN, P.D. 2001. PAST: Palaeontological Statistic software package for education and data analysis. Palaeontological Electronica. 4(1):1-9.

HARTMANN, M.T., GARCIA, P.C.A., GIASSON, L.O.M. \& HARTMANN, P.A. 2008. Anfíbios. In A fauna das áreas de influência da Usina Hidrelétrica Quebra Queixo (J.J. Cherem \& M. Kammers, org.). Erechim, p.89-107.

HAYES, T.B., COLLINS, A., LEE, M., MENDOZA, M., NORIEGA, N., STUART, A.A. \& VONK, A. 2002. Hermaphroditic, demasculinized frogs after exposure to the herbicide atrazine at low ecologically relevant doses. PNAS. 99(8):5476-5480. http://dx.doi.org/10.1073/pnas.082121499

HAYES, T.B., KHOURY, V., NARAYAN, A., NAZIR, M., PARK, A., BROWN, T., ADAME, L., CHAN, E., BUCHHOLZ, D., STUEVE, T. \& GALLIPEAU, S. 2010. Atrazine induces complete feminization and chemical castration in male African clawed frogs (Xenopus laevis). PNAS. 107(10):4612-4617. http://dx.doi.org/10.1073/pnas.0909519107

INSTITUTO BRASILEIRODE GEOGRAFIAE ESTATÍSTICA-IBGE. 2002. Mapa de clima do Brasil. Departamento de Recursos Naturais e Estudos Ambientais. http://geoftp.ibge.gov.br/mapas/tematicos/mapas_murais/ clima.pdf (último acesso em 21/06/2012).

INSTITUTO SOCIO-AMBIENTAL, 2003. Plano de Manejo do Parque Estadual Fritz Plaumann.

INTERNATIONAL UNION FOR CONSERVATION OF NATURE - IUCN. 2011. IUCN Red List of Threatened Species. version 2011.2. www.iucnredlist.org (último acesso em 16/11/2011).

IOP, S., CALDART, V.M., SANTOS, T.G. \& CECHIN, S.Z. 2011. Anurans of Turvo State Park: testing the validity of Seasonal Forest as a new Biome in Brazil. J. Nat. Hist. 45:2443-2461. http://dx.doi.org/10.1080/ 00222933.2011.596951

KLEIN, R.M. 1978. Mapa fitogeográfico do Estado de Santa Catarina. Itajaí.

KOPP, K., ANTONIOSI FILHO, N.R., ALVES, M.I.R. \& BASTOS, R.P. 2007. Publicações sobre efeitos de pesticidas em anfíbios no período de 1980 a 2007. Rev. Multiciênc. 8:173-186.

KREBS, C.J. 1999. Ecological methodology. Menlo Park, Addison Wesley Longman.

KRISHNAMURTHY, S.V., MEENAKUMAR, D., GURUSHANKARA, H.P. \& VASUDEV, V. 2008. Nitrate-Induced Morphological Anomalies in the Tadpoles of Nyctibatrachus major and Fejervarya limnocharis (Anura: Ranidae). Turk. J. Zool. 32:239-244.
KWET, A. \& FAIVOVICH, J. 2001. Proceratophrys bigibbosa species group (Anura: Leptodactylidae), with description of a new species. Copeia. 2001(1):203-215. http://dx.doi.org/10.1643/00458511(2001)001[0203:PBSGAL]2.0.CO;2

KWET, A. 2006. Bioacoustics in the genus Adenomera (Anura: Leptodactylidae) from Santa Catarina, southern Brazil. In: Proceedings of the 13th Congress of the Societas Europaea Herpetologica (M. Vences, J. Köhler, T. Ziegler \& W. Böhme, eds.). Bonn, p.77-80.

KWET, A., LINGNAU, R. \& DI-BERNARDO, M. 2010. Pró-Mata: Anfíbios da Serra Gaúcha, sul do Brasil - Amphibien der Serra Gaúcha, Südbrasilien - Amphibians of the Serra Gaúcha, South of Brazil. 2. ed. Brasilien Zentrum der Universität Tübingen, Tübingen.

LAJMANOVICH, R.C., IZAGUIRRE, M.F. \& CASCO, V.H. 1998. Paraguat tolerance and alteration on internal gill structure of Scinax nasica tadpoles (Anura: Hylidae). Arch. Environ. Contam. Toxicol. 34:364-369. http:// dx.doi.org/10.1007/s002449900331

LAJMANOVICH, R., LORENZATTI, E., DE LA SIERRA, P., MARINO, F., STRINGHINI, G. \& PELTZER, P. 2003. Reduction in the mortality of tadpoles (Physalaemus biligonigerus; Amphibia: Leptodactylidae) exposed to Cypermethrin in presence of aquatic ferns. Fresen. Environ. Bull. 12:1558-1561.

LAJMANOVICH, R., DE LA SIERRA, P., MARINO, F., PELTZER, P., LENARDÓN, A. \& LORENZATTI, E. 2005. Determinación de residuos de organoclorados en vertebrados silvestres del litoral fluvial de Argentina. INSUGEO, Miscelánea. 14:255-262.

LEITE, M.A.S. \& LEÃO, R. 2009. Diagnóstico e caracterização da sub-bacia do Rio dos Queimados. Concórdia: Consórcio Lambari: Comitê do Rio Jacutinga e Contíguos.

LINGNAU, R. 2009. Distribuição temporal, atividade reprodutiva e vocalizações em uma assembleia de anfíbios anuros de uma Floresta Ombrófila Mista em Santa Catarina, sul do Brasil. Tese de Doutorado, Pontifícia Universidade Católica do Rio Grande do Sul, Porto Alegre.

LUCAS, E.M. 2008. Diversidade e conservação de anfíbios anuros no Estado de Santa Catarina, sul do Brasil. Tese de Doutorado, Instituto de Biociências, Departamento de Ecologia, Universidade de São Paulo, São Paulo.

LUCAS, E.M. \& FORTES, V.B. 2008. Frog diversity in the Floresta Nacional de Chapecó, Atlantic Forest of Southern Brazil. Biota Neotrop. 8(3): http:/ www.biotaneotropica.org.br/v8n3/pt/abstract?article+bn00508032008.

LUCAS, E.M. \& GARCIA, P.C.A. 2011. Amphibia, Anura, Hylidae Rafinesque, 1815 and Hylodidae Günther, 1858: Distribution extension and new records for Santa Catarina, southern Brazil. Check List. 7(1):13-16.

LUCAS, E.M. \& MAROCCO, J.C. 2011. Anurofauna (Amphibia, Anura) em um remanescente de Floresta Ombrófila Mista no Estado de Santa Catarina, Sul do Brasil. Biota Neotrop. 11(1): http://www.biotaneotropica. org.br/v11n1/pt/abstract?article+bn01211012011.

MACHADO, I., MOREIRA, L.F.B. \& MALTCHIK, L. 2012. Effects of pine invasion on anurans assemblage in southern Brazil coastal ponds. AmphibiaReptilia. 33:227-237. http://dx.doi.org/10.1163/156853812X638518

MANN, R.M., BIDWELL, J. R. \& TYLER, M. J. 2003. Toxicity of herbicide formulations to frogs and the implications for product registration: a case study from western Australia. Applied Herpetology. 1:13-22. http://dx.doi. org/10.1163/157075403766451199

MANLY, B.F.G. 2000. Multivariate statistical methods-a primer. Chapman and Hall/CRC, Boca Raton.

MAROCCO, J.C., LUCATELLI, M., CALDART, V.M., BASTIANI, V.I.M. \& LUCAS, E.M. 2011. Diversidade e conservação de anuros em ambientes naturais e alterados no município de Caxambu do Sul, estado de Santa Catarina, Sul do Brasil. In IX Congresso Latinoamericano de Herpetologia e V Congresso Brasileiro de Herpetologia: Novos Rumos da Herpetologia Latinoamericana. Curitiba.

MARTIN, L.J. \& MURRAY, B.R. 2011. A predictive framework and review of the ecological impacts of exotic plant invasions on reptiles and amphibians. Biol. Rev. 86:407-419. http://dx.doi.org/10.1111/j.1469185X.2010.00152.X

MEDEIROS, J.D. 2006. Os Estados da Mata Atlântica: Santa Catarina. In Mata Atlântica: uma rede pela floresta (M. Campanili \& M. Prochnow, org.). Brasília, p.45-47. 
MITTERMEIER, R.A., GIL, P.R., HOFFMANN, M., PILGRIM, J., BROOKS, J., MITTERMEIER, C.G., LAMOURUX, J. \& FONSECA, G.A.B. 2004. Hotspots revisited: earth's biologically richest and most endangered terrestrial ecoregions. Cemex, Washington.

MYERS, N., MITTERMEIER, R.A., MITTERMEIER, C.G., FONSECA, G.A.B \& KENT, J. 2000. Biodiversity hotspots for conservation priorities. Nature 403:853-858. http://dx.doi.org/10.1038/35002501

NARVAES, P., BERTOLUCI, J. \& RODRIGUES, M.T. 2009. Composição, uso do hábitat e estações reprodutivas das espécies de anuros da floresta de restinga da Estação Ecológica Juréia-Itatins, sudeste do Brasil. Biota Neotrop. 9(2): http://www.biotaneotropica.org.br/v9n2/pt/ abstract?article+bn02009022009.

OLIVEIRA-FILHO, A.T., JARENKOW. J.A. \& RODAL, M.J.N. 2006. Floristic relationships of seasonally dry forests of eastern South America based on tree species distribution patterns. In Neotropical savannas and dry forests: Plant diversity, biogeography and conservation (R.T. Pennington, J.A. Ratter \& G.P. Lewis, eds.). CRC Press - Taylor and Francis Group, Boca Raton, cap.7, p.159-192. The Systematics Association Special volume Series, n.69.

PELTZER, P.M., LAJMANOVICH, R.C. \& BELTZER, A.H. 2003. The effects of habitat fragmentation on amphibian species richness in the floodplain of the Middle Paraná River, Argentina. Herpetol. J. 13:95-98.

PENNINGTON, R.T., LAVIN, M. \& OLIVEIRA-FILHO, A.T. 2009. Woody plant diversity, evolution and ecology in the tropics: perspectives from seasonally dry tropical forests. Ann. Rev. Ecol. Evol. Syst. 40:437-457. http://dx.doi.org/10.1146/annurev.ecolsys.110308.120327

PINTO, L.P., BEDÊ, L., PAESE, A., FONSECA, M., PAGLIA, A. \& LAMAS, I. 2006. Mata Atlântica Brasileira: os desafios para conservação da biodiversidade de um hotspot mundial. In Biologia da Conservação: essências (C.F.D. Rocha, org.). São Paulo, p.69-96.

PYRON, A. \& WIENS, J.J. 2011. A large-scale phylogeny of Amphibia including over 2,800 species, and a revised classification of extant frogs, salamanders, and caecilians. Mol. Phylogenet. Evol. 61(2):543-583. http:// dx.doi.org/10.1016/j.ympev.2011.06.012

RELYEA, R.A. 2005a. The lethal impact of roundup on aquatic and terrestrial amphibians. Ecol. Appl. 15:1118-1124. http://dx.doi.org/10.1890/04-1291

RELYEA, R.A. 2005b. The impact of insecticides and herbicides on the biodiversity and productivity of aquatic communities. Ecol. Appli. 15:618-627. http://dx.doi.org/10.1890/03-5342

RICKLEFS, R.E. \& SCHLUTER, D. 1993. Species diversity in ecological communities: historical and geographical perspectives. University of Chicago Press, Chicago.

RIBEIRO, M.C., METZGER, J.P., MARTENSEN, A.C., PONZONI, F.J. \& HIROTA, M.M. 2009. The Brazilian Atlantic Forest: How much is left, and how is the remaining forest distributed? Implications for conservation. Biol. Conserv. 142:1141-1153. http://dx.doi.org/10.1016/j. biocon.2009.02.021

ROCHA, C.F.D., HATANO, F.H., VRCIBRADIC, D. \& VAN SLUYS, M. 2008. Frogs species richness, composition and $\beta$-diversity in coastal Brazilian restinga habitats. Braz. J. Biol. 68:101-107. http://dx.doi. org/10.1590/S1519-69842008000100014

ROHLF, F.J. 2000. NTSYS 2.1: Numerical Taxonomic and Multivariate Analysis System. Exeter Software, New York. CD-ROM.

ROMESBURG, H.C. 1984. Cluster analysis for researchers. Robert E. Krieger, Malabar.

SANTA CATARINA. Governo do Estado. 2010a. Decreto Estadual nº 2.956, de 20 de janeiro de 2010. Institui o Corredor Ecológico Timbó na região da Bacia Hidrográfica do Rio Timbó, região hidrográfica RH5 do Estado de Santa Catarina - Planalto de Canoinhas, situado entre as Latitudes $26^{\circ} 00^{\prime} 06^{\prime} \mathrm{S}$ e $26^{\circ} 50^{\prime} 03^{\prime \prime} \mathrm{S}$ e as Longitudes $50^{\circ} 18^{\prime} 52^{\prime \prime} \mathrm{W}$ e $51^{\circ} 24^{\prime}$ '47' W, com 4.997,48 km² de extensão. Florianópolis, 20 jan.
SANTA CATARINA. Governo do Estado. 2010b. Decreto Estadual n ${ }^{\circ} .2 .957$, de 20 de janeiro de 2010. Institui o Corredor Ecológico Chapecó na região da Sub-Bacia Hidrográfica do Rio Chapecó, região hidrográfica RH2 - Meio Oeste do Estado de Santa Catarina, situado entre as Latitudes $26^{\circ} 21^{\prime} 33^{\prime \prime} \mathrm{S}$ e $26^{\circ} 54^{\prime} 27^{\prime \prime} \mathrm{S}$ e as Longitudes $51^{\circ} 23^{\prime} 30^{\prime \prime} \mathrm{W}$ e $52^{\circ} 52^{\prime} 28^{\prime \prime}$ W, com 5.170,47 km² de extensão. Santa Catarina, 20 jan.

SANTOS, A.J. 2003. Estimativas de riqueza em espécies. In Métodos de estudos em biologia da conservação e manejo da vida Silvestre (L. Cullen Junior, R. Pudran \& C. Valladares-Pádua, eds.). Curitiba, p.19-41.

SCHNEIDER, M.I., SANCHEZ, N., PINEDA, S., CHI, H. \& RONCO, A. 2009. Impact of glyphosate on the development, fertility and demography of Chrysoperla externa (Neuroptera: Chrysopidae): Ecological approach. Chemosphere. 76(10):1451-1455. http://dx.doi. org/10.1016/j.chemosphere.2009.05.029

SCOTT JUNIOR, N.J. \& WOODWARD, B.D. 1994. Relevamientos de lugares de reproducción. In Measuring and Monitoring Biological Diversity: standard methods for amphibians (W.R. Heyer, M.A. Donnelly, R.W. McDiarmid, L.A.C. Hayek \& M.S. Foster). Washington, p.113-120

SILVANO, D.L. \& SEGALLA, M.V. 2005. Conservação de anfíbios no Brasil. Megadiversidade 1(1):79-86.

SOCIEDADE BRASILEIRA DE HERPETOLOGIA - SBH. 2012. Lista de espécies de anfíbios do Brasil. www.sbherpetologia.org.br/checklist/ anfibios.htm (último acesso em 14/06/2012).

TABARELLI, M., PINTO, L.P., SILVA, J.M.C., HIROTA, M.M. \& BEDÊ, L.C. 2005. Desafios e oportunidades para a conservação da biodiversidade na Mata Atlântica brasileira. Megadiversidade. 1(1):132-138.

TERNUS, R.Z., SOUZA-FRANCO, G.M., ANSELMINI, M.E.K., MOCELLIN, D.J.C. \& DAL MAGRO, JACIR. 2011. Influence of urbanisation on water quality in the basin of the upper Uruguay River in western Santa Catarina, Brazil. Acta Limnol. Bras. 23:189-199. http:// dx.doi.org/10.1590/S2179-975X2011000200009

TOLEDO, L.F., ZINA, J. \& HADDAD, C.F.B. 2003. Distribuição espacial e temporal de uma comunidade de anfíbios do Município de Rio Claro, São Paulo, Brasil. Holos Environmental. 3(2):136-149.

TOLEDO, L.F., GARCIA, P.C.A., LINGNAU, R. \& HADDAD, C.F.B. 2007. A new species of Sphaenorhynchus (Anura: Hylidae) from Brazil. Zootaxa. 1658:57-68.

TOLEDO, L.F., CARVALHO-E-SILVA, S.P., SÁNCHEZ, C., ALMEIDA, M.A. \& HADDAD, C.F.B. 2010. The review of the Brazilian Forest Act: harmful effects on amphibian conservation. Biota Neotrop. 10(4): http:// www.biotaneotropica.org.br/v10n4/en/abstract?article+bn00410042010.

VASCONCELOS, T.S. \& ROSSA-FERES, D.C. 2005. Diversidade, distribuição espacial e temporal de anfíbios anuros (Amphibia, Anura) na região Noroeste do estado de São Paulo, Brasil. Biota Neotrop. 5(2): http:// www.biotaneotropica.org.br/v5n2/pt/abstract?article+BN01705022005.

VITALI, M. \& UHLIG, V.M. 2010. Unidades de Conservação de Santa Catarina. Revista Sustentabilidade em Debate. 1:45-63.

WACHLEVSKI, M. \& ROCHA, C.F.D. 2010. Amphibia, Anura, restinga of Baixada do Maciambu, municipality of Palhoça, state of Santa Catarina, southern Brazil. Check List. 6(4):602-604.

WANDSCHEER, A.C.D., BORELLA, J., BONATTI, L.C. \& PASTORINI, L.H. 2011. Atividade alelopática de folhas e pseudofrutos de Hovenia dulcis Thunb. (Rhamnaceae) sobre a germinação de Lactuca sativa $\mathrm{L}$. (Asteraceae). Acta Bot. Bras. 25(1):25-30.

ZAR, J. H. 1999. Biostatistical analyses. Prentice Hall, New Jersey.

ZIMMERMAN, B.L. \& SIMBERLOF, D. 1996. An historical interpretation of habitat use by frogs in a Central Amazonian Forest. J. Biogeogr. 23:27-46. http://dx.doi.org/10.1046/j.1365-2699.1996.d01-218.x

ZINA, J., ENNSER, J., PINHEIRO, S.C.P., HADDAD, C.F.B. \& TOLEDO, L.F. 2007. Taxocenose de anuros de uma mata semidecídua do interior do Estado de São Paulo e comparações com outras taxocenoses do Estado, sudeste do Brasil. Biota Neotrop. 7(2): http://www.biotaneotropica.org. br/v7n2/pt/abstract?article+bn00607022007 